\title{
THE RELATION BETWEEN THE VIEW ON THE LANGUAGE ANd Educational IdeOlogy in The EARLy MeiJi Period IN JAPAN THROUGH THE DISCOURSE OF REGIONALISM
}

\author{
ICHIMIYA Yufuko \\ University of Ljubljana \\ yfk138@gmail.com
}

\begin{abstract}
In this article, the Japanese language situation in early Meiji period will be analyzed from the viewpoint of the provinces. In concrete terms, the origin of the idea that "an opaque language yields an unlcear ideology" - we can often find such a discourse through Meiji, Taisho and early Showa period - will be searched for by using primary sources in northern Kyushu, the southern part of Japan. This kind of idea can be seen in the writings of teachers and professors. Consequently, educational theories and teaching methods which had spread over the country in that period will be clues to analyze this subject. Moreover, I will try to compare the concept of "opaque language" in the Taisho period, during which dialects were considered as the representative example of such a language, with what was considered "opaque language" in the early Meiji period, when the definition of dialect and the concrete form of the standard language were still vague.
\end{abstract}

\section{Keywords}

national language policy, vernacular, opaque language, educational thought, late 19th century Japan

\section{Izvleček}

V članku bom analizirala jezikovno situacijo v zgodnjem obdobju Meiji z vidika podeželja. Konkretno rečeno, bom izvor ideje, da "nejasen jezik ustvarja nejasno ideologijo" - skozi obdobja Meiji, Taisho in zgodnje obdobje Showa je bil tak diskurz precej pogost - raziskala z uporabo primarnih virov iz severnega Kyushuja na jugu Japonske. Taka ideja se pogosto pojavlja v besedilih učiteljev in profesorjev, zato bodo teorije izobraževanja in učne metode, ki so se razširile po deželi v tistem času, ključ do analize tega predmeta. Nadalje bom poskušala primerjati koncept "nejasnega jezika" v obdobju Taisho, ko so primer takega jezika predstavljala narečja, s tem, kar je "nejasen jezik" pomenil v zgodnjem obdobju Meiji, ko sta bili definicija narečja in konkretna oblika standardnega jezika še zelo nejasni.

\section{Ključne besede}

politika nacionalnega jezika, narečje, nejasen jezik, ideologija izobraževanja, konec 19. stoletja na Japonskem 


\section{Introduction}

A number of scientific researches carried out from 1990 onwards have sought to explain the development of the "Japanese national language" which was a result of the formation of the Japanese nation state and a clear political doctrine in Modern Japan. In the present study, the issues regarding the "Japanese national language" of that period will be discussed from the point of view of regionalism with reference to the above mentioned researches. I am going to put special emphasis on the standard Japanese language, one of the central issues of the national language policy, on its function and diffusion in the inland areas of Japan. Furthermore, I intend to examine the linguistic history of Modern Japan - a topic already presented in other scientific researches - from a deeper perspective by contrasting the ideas of the Japanese govenment and intellectuals, the creators of the Japanese national language scheme, with the ideas of the general public living in the provincial areas in Modern Japan.

More specifically, I am going to focus on the analysis of the situation in the educational system of the Oita prefecture. This is due to the fact that at the time the issue of the Japanese national language was mostly discussed within the context of education, which is why most of the sources published within that region are also related to education.

In 1914, the magazine Chūōkoron (Central Review) published a dissertation by Mukai Gunji, a professor from Keiō University. In the light of the outbreak of the First World War, his article was an attempt to re-define the concept of "national education" and it can be said that it offered a view on the language of that period in Japan:

... Clear thoughts go hand in hand with a developed language. Likewise, a developed language can yield clear thoughts. On the other hand, if the language is unclear and if consequently the thoughts cannot develop sufficiently, the opacity of the language results in the opacity of the thoughts. In our country, the lanugage of the people in the Tōhoku region is extremely opaque. If one tries to look inside the heads of those people, one can see that not only their language, but also their thoughts are not clear. This phenomenon results from the fact that because a clear language has not illuminated the intellect, the latter does not develop as it should. Therefore it can be said that those countries where the language is not properly developed have reached a lower level of civilization compared to the countries with a developed language... (Mukai, 1914, p.56)

To summarize Mukai's view on the language: clear thoughts can developed from a clear language, which proves that the intellect is developed too. Furthermore, countries with a developed language have reached a high level of civilization. On the contrary, an opaque language hampers the development of the intellect, which then result in unclear thoughts. Therefore, it can be said that languages in underdeveloped countries are also underdeveloped. In other words, Mukai claims that the language has a proportional effect on the thoughts and the intellect, and consequently also on the development of a civilization. 
It also should be noted that the language spoken in the Tōhoku region - the Tōhoku dialect - is presented as an "opaque language". In other words, dialects are seen as typical examples of "opaque, underdeveloped and uncivilised" languages. Thus, from the point of view of the "national education" as described by Mukai - a system which treats the nation as a big uniform group and seeks to eradicate differences between individuals -, dialects were not only criticised for hindering the development of the ideas and the intellect - the idea in Modern Japan was also to decrease the diversity of the dialects across different regions.

Mukai's strong emphasis on the idea that "an opaque language yields an opaque ideology" serves as the basis for the homogenization of dialects. During the first 20 years of the Meiji Period, when the definition of "dialect" was still vague, some elementary school teachers expressed similar ideas:

...If the language is opaque or incoherent, ideas and thougts are also opaque or incoherent. Such language also affects written expression... (Mino, 1888, p.7)

... Students can also evaluate their ideas through the quality of their language. (Matsubara, 1888)

We can detect two different tendecies in all the ideas mentioned above. One of them is the search of a basis for correlation between the language and the development of ideology, and idea supported by the discourse related to the field of education. The other is the effort to explain the concept of an "opaque language" or, in other words, a language that needs to be homogenized within the context of the Modern Japan where the definition of a dialect and the concrete form of the standard language were still vague.

In the present dissertation, I am going to rely on secondary sources to outline general characteristics of the situation in the sphere of language in the Meiji Period in Japan. Moreover, I am going to analyse the view on the language shared by the teachers active in the provincial areas within the context of the educational ideology of that period. In doing so, I am going to refer to the discourses of that period which deal with the correlation between the language and the ideology. Furthermore, on the basis of the school administration regulations, I am going to speculate about the lingustic elements that were thought better to be avoided at schools. My primary sources mainly consist of the reports and essays published or reprinted in Oita kyōritsu kyōiku zasshi, an exclusive publication intended for the teachers active in the Oita prefecture.

\section{Language in the Early Meiji Period in Japan}

Most experts agree that the year 1900 represents a milestone for the issue of the "national language"in Modern Japan. It was the year when a temporary Ministry of Education founded the Board for National Language, and the Japanese language was introduced as a subject in primary schools, which also led to the creation of Japanese 
language textbooks. A systematic creation of the "Japanese national language" was under way. In the Early Meiji Period, which is the subject of the present dissertation, the ideology that propelled the above mentioned systematization of the national language was still at a developing stage. Also, the general view on dialects in the early Meiji Period differed from that in the second half of the Meiji period.

One of the characteristics of the general stance on dialects in the early Meiji Period is that the essential question regarding the definition of a dialect remained unanswered. Here, I would like to focus on two concrete examples.

In 1880, a Public Lecture on Dialects Across Regions was held at the Imperial University. Students, including Tanakadate Aikitsu and Inoue Enryō - both intellectuals in the making and highly influential in the language policy later on - held speeches in their dialects. However, what these speakers stressed were the similarities between their languages and the language spoken in Tokyo. Also, they claimed that the lexical, inflectional, accentual and other such differences existed due to social and gender differences originating from the class system of the Edo Period (Osa, 1998, p.156).

The other example are articles about dialects published in magazines all around the country. Such publications became very frequent in the first 20 years of the Meiji Period. Due to the methodology used in those articles, they were not particularly acclaimed in the academic circles, but they still gave to the readers an opportunity to become acquainted with a different world outside their own regions, and inspired them to reflect on their own language (Yasuda, 1999, p.43). There were also studies on dialects published in different regions in that period, but most of them were merely collections of words. Among those publications is also the official report on the results of a study on dialects ordered by the government which, however, also does not include a description of the structure of a dialect or its phonetic system but only contains a list of nouns. In contrast with a national dialect survey performed in 1902 by the State Committee for Japanese Language Research, aiming to spread the standard Japanese language and considering dialects as an enemy that needs to be destroyed (Lee, 1996, p.144), the studies mentioned above prove that the researchers actually did not operate with a common concept of dialect or a common concept of classification (Osa, 1998, p.159).

However, in certain discourses, dialects are also regared as a linguistic issue. For example, in Shuisho, a study of dialects by a group of different authors with Miyake Yonekichi in the pivotal role, the dialect is seen as a result of the barrier created due to geographical factors and the feudal system (Miyake, 1929, p.849). However, that barrier can gradually be lifted, since the progress of the society and technology offers things like steamboats, trains and telegraphs. Osa (1998, p.161) analyses this point of view as follows: What is important here is that although Miyake, who stresses the progress of the society, sees dialects as a linguistic phenomenon resulting from the Japanese feudal system, he does not consider it as a problem that needs to be solved. 
Thus it can be said that in that particular period dialects were not necessarily seen as a subject that has to be homogenized, changed and eradicated like later on during the movement for the unification of the written and spoken styles of the Japanese language. Some authors, for example Aota Misao in his Reformation of Dialect (Hōgenkairyōron s, 1888), supported a planned disintegration of dialects. However, as Yasuda (1999, p.53) points out, this was more an expression of exasperation over the fact that people from different regions find it hard to communicate, rather than a manifesto for the unification of the Japanese lanugage for reasons of good taste.

To summarize, this part of my study offers a reflection on the situation in the sphere of language in the early Meiji Period from the perspective of dialects. It can be said that in this period, the concept of "dialect" representing a contrast to the concept of "the standard language" was not yet formed. Moreover, the definition of a dialect was not yet formulated, and the initiatives to eradicate dialects were not as intense as later on.

\section{The Relation Between the Language and Ideology in the Sphere of Education}

First, I would to like to return to Mukai's stance on language which was discussed at the beginning. According to Mukai (1914), an opaque language, typically represented by a dialect, yields an unlcear ideology. And, as it was discussed in the previous part of this study, the same stance could frequently be found in the first 20 years of the Meiji Period, when the position of dialects within the scope of the "national language issue" was not yet clear.

In this section, I am first going to discuss in detail the study written by the elementary school teachers from the Oita prefecture in 1888. I am also going to attempt to make a connection between the methods of education of that time and Mukai's formula described above.

\subsection{The Stance of the Provincial School Teachers -Mino Teizo ${ }^{1}$ : The Importance of Language Practice (Gengo renshū no hitsuyō)}

At the beginning of his study, the author, Mino Teizo (1888) treats "text" and "language", or, in other words, "written language" and "spoken languagae" as means of expressing ideas. Furthermore, the author claims that the education is crucial for the development of these two elements, but he also warns about the neglect of the "spoken language":

\footnotetext{
${ }^{1}$ The surname is written in Chinese characters which have two possible pronunciations, Mino or Yoshino, but no information is given as to how his surname was pronounced.
} 
Ever since early times, our country has emphasized the importance of the script and made it the basis of education. On the other hand, spoken language has necever received any consideration. A grown-up man who is well versed in spoken language has even been the subject of public scorn. Such mentality is still influencing the situation nowadays and a portion of educational experts do not devote any attention to the methods of teaching spoken language. (Mino, 1888, p.6)

Two reasons for dismissing the spoken language are given here. One of them is the emphasis on the Japanese script in the educational system in Japan, which was present even before Modern Japan. The other reason lies in the tendency to trivialize ortaorical skills. One of the students from the Fukuoka prefecture made a reference to the latter:

Talkativeness is considered to be an embarrassing quality in men. This particular point of view is deeply rooted in the mentality of the people in Kyūshū. (Yano, 1907)

Therefore, it can be said that the tendency to trivialize the spoken language was quite alive at least in the northern part of Kyūshū.

So why is teaching language so important? Mino (1888, p.6) provides two reasons. One lies in the fact that an unclear and incoherent lanugage may lead to serious misunderstandings, as people express their thoughts in order to convey them to other people. The other reason is that the significance of a language lies in its clarifying force - it is a means by which we explain concepts.

The reason why we stress the importance of the language is not only that the lanugage is a tool we use to express thoughts, but also a tool with which we can explain the concepts that are stored In our minds and which serves as an aid to our memory. In other words, with the help of sensory organs we create images about the nature of things and their shapes. And if we think about something and then express it with words again and again, we render the concepts more tangible and therefore easier to accumulate. (Mino, 1888, p.6)

In this passage the emphasis is on the crucial role of the language as the medium between the knowledge and memory - language gives shape to concepts and acts as an aid to the memory which then deepens our thoughts.

On the basis of the arguments described above, Mino also advocates the idea that not only students but also teachers should make an effort to practise their language. The author also defines the sort of attitude that teacher should take towards the language spoken in class:

Even those teachers who recognize the importance of language practice sometimes neglect to correct language anomalies uttered by their students, such as inadequate or incorrect vocabulary, vague or unclear word endings etc. Some teachers even correct these mistakes themselves. Such teaching methods surely cannot improve the students' language. (Mino, 1888, pp.6-7) 
If a teacher notices unclear word endings, inadequate vocabulary or even erroneous use of words, it is his/her duty to correct such anomalies. However, the teacher should not simply find the correct word or its ending for the students, but encourage the students to do that themselves. That is because, as Mino (1888) points out, the concepts are framed through language, which in turn means that if the language is incoherent the concepts expressed with that language will be incoherent too.

In the study written by Mino one can sense the influence of Western modern linguistics which put an emphasis on the spoken language. In Oita kyōritsu kyōiku zasshi, articles from similar magazines published in other provinces appeared, and theories from the central intellectual circles could also be found. Therefore it could be assumed that the idea that "an opaque language equals unlcear thoughts" is a definition derived from a certain theory. In the next section, I am going to look into this particular issue.

\section{The Spread of Pestalozzism and Object Lessons}

It was not until the issue of the 3rd Decree on Elementary Schools in 1900 that the Japanese language started to be taught as a subject at schools. However, even before the decree in question, similar subjects had been taught at schools in the early Meiji Period, for example reading skills, writing skills and calligraphy. In order to better understand the methods used during the lessons in that period, one can consult The Manual for Teachers (Kуо̄ju hōsho). One of the first principals of the so-called "normal school" (which later became the Tokyo Normal School), Morokuzu Nobuzumi, adopted the following stance:

Although the education of a child includes the acquisition of academic skills, it should, at the beginning, primarily stimulate the child's perceptiveness and develop his/her intellect. In order to develop the child's itellect, the educational process should stimulate the child to think about different phenomenons, their characteristics and practical applicability. Children are very perceptive, quick-witted and change easily, which is why the early period in their lives should not go to waste. (Morokuzu, 1873)

The Shōgakkō kyōshi hikkei displays characteristics of class teaching methods used by Marion McCarrell Scott, a normal school teacher from the USA. Scott (18431922) was the first teacher at Tokyo State Normal School, where she was active for 10 years bewteen 1871 and 1881, and the person who introduced to Japan different teacher training methods and modern class teaching methods. Scott's educational philosophy included the so-called object lessons. This teaching method was a part of the Pestalozzism doctrine which was very popular in the USA at the time. The point of object lessons is to teach children by showing them or putting them in contact with concrete things and phenomenons. In fact, Morokuzu's idea that students should 
develop their "intellect" by "studying" and "contemplating" about "things" and their "nature" reflects the Pestalozzist concept of object lessons.

Furthermore, the teaching method in question displays another specific characteristic and that is the extensive use of dialogues. Almost every teaching manual from that period includes examples of dialogues as teaching methods. In some cases there are certain differences as far as the terminology is concerned, but the content and the method is always almost the same. It can be said that the method taught by Scott was the method of object lessons with a strong emphasis on dialogues.

I would like to examine a concrete example of the dialogue method mentioned above. I am going to provide an example of a discussion bewteen the student and the teacher:

TEACHER: What is kaki?

STUDENT: It is a fruit from which a kaki tree grows.

TEACHER: What do we use it for?

STUDENT: It is a sort of fruit and we use it for food.

TEACHER: How do we eat it?

STUDENT: Usually we eat it raw, but sometimes we dry it. (Calkins, Kaneko \&

Takahashi. 1875)

This kind of teaching method, widely used in the USA in that period, is based on the philosophy of developmentalism - development starting with the presentation of the substance - which is also reflected in the example above.

Kaisei kyōju jutsu (A Revision of Teaching Techniques, 1883) by Wakabayashi Torasaburō and Shirai Kowashi reached a high level of popularity among normal schools, which resulted in the spread of the inclination towards Pestalozzism all over the country. In Kaisei kyōju jutsu there are many examples of the dialogue method discussed above. Still, although these developments helped to consolidate the philosophy of developmentalism, they steered the later development of the dialogue method, used in elementary education, in a direction away from the original ideas of Pestalozzism. Itō (1995) analyzes the situation as follows:

Since dialogues are based on form rather than meaning, it can be said that the dialogue technique, originating from the study (Kaisei kyōju jutsu) in question, was moving away from developmentalism and towards formalism. Moreover, since each concrete illustration of the dialouge method in the study is written very meticulously, it can be presumed that in class, considering the influence of Kaisei kyōju jutsu, these illustrations were understood very literally and also put into practise as such. Thus, the Pestolizzist dialouge method which came from the UK and the USA to Japan, began to represent a bond between the the teacher and the student (Ito, 1995, pp.8788)

This method is reminiscient of the so-called "repetitive reading technique" used in the early modern period, whereby the teacher asked a question and the students gave a detailed answer which had been prepared in advance. The goal was to memorize the answer. The dialogue method yielded the tendency to equalize the acquisition of 
knowledge and the accuracy of the memory. All in all, because of the prevalent idea that a clear language and clear thoughts are proportionally related to each other, it can be safely said that Pestolizzism changed when it was accepted in Japan.

I would like to go back to Mukō's and Mino's points of view - both authors claim that clear thoughts require a clear language. However, as a typical example of an "opaque language" Mukai points out the dialect, whereas Mino mentions inadequate or erroneous words - but was that really the stance shared by the teachers of that period? In the next section, I am going to examine individual items from the regulations of school administration and attempt to discover what was considered as "opaque language" in elementary education of the early Meiji period.

\section{The Clarity of Language Required from Students (from the School Administration Rules)}

In May of 1890, Kuroda Sadaharu, a teacher and a tutor at the advanced normal school, published a report on teaching methods for individual subjects in Oita kyōritsu kyoiku zasshi. It is a report for the Ministry of Education about Kuroda's research performed at elementary schools throughout the prefecutre. Apart from teaching methods for individual subjects, the report suggests the ways in which students should change their habits. Examples:

The following flaws have been discovered in the habits and characters of the students:

- violent language

- excessive talkativeness (especially with female students)

- lying

- tale-telling

- obscene choice of words; singing vulgar songs

- self-righteousness; interfering with other people's business (especially female students)

- impropriety

- loudness

- undignified behaviour

- showing inclination towards gambling (Kuroda, 1889)

The flaws mentioned above include obscenity, talkativeness, deceit and vulgarity. The flaws that could be connected with dialects are obscenity and vulgarity, although there is no direct indication of that in the report. However, in the following year, a research was conducted at elementary schools with simplified programmes throughout the prefecture. The report describes attempts to make the students use word endings and forms which express modesty, for example ARIMASU and GOZAIMASU (Hojo, 1890, pp.39-40).

Surely, this view speaks for the correction of dialects. However, it can be said that by pointing out standard sentence endings, the report also reflects the importance of avoiding "vague" inflections, which is an idea supported by Mino (1888). 
During the same period, rules regarding the administration of schools from other prefectures were published in Oita kyōritsu kyōiku. At the time, elementary education was not yet a well-organized system, and elementary school teachers sought concrete examples that could be used in practice. Listed below are regulations concerning language which have been taken from three articles:

A. The Teaching Methods at the Elementary School Affiliated to The Normal School of the Shizuoka Prefecture (1891)

(7) Students' language should be accurate and clear, especially word endings;

(8) If a student speaks with voice that is too quite to be heard, the teacher should correct that flaw by always reminding the student;

(9) The teacher should never be lenient, whether it is a student's pose, language or voice that needs correcting

B. The Rules of Behaviour at the Elementary School Affiliated to The Normal School of the Mie Prefecture (1893)

Item 3: Rules Concerning Language and Behaviour

(1) Students must show respect towards property and other people. They must also adopt a humble attitude. Boys must be decisive and energetic, whereas girls must be calm and dignified.

(2) Students must speak with a clear voice, and use a mild, dignified language

(3) Students must be careful not to use rude language when addressing their superiors

Item 7: Rules of Behaviour in Classroom

(1) Students must make themselves clear when speaking. They should always finish their sentences and make sure they pronounce word endings clearly.

C. Guidelines for Teaching at the Elementary School Affiliated to The Normal School of the Chiba Prefecture (1893)

The goal is to give students the knowledge and skills they will need in life, and to raise them to become moral people and good citizens

... The graduates of the elementary course are expected to acquire the following characteristics: a clear language, a lively character, willingness to cultivate their bodies and their spirits

... the graduates of the advanced course are expected to acquire the following characteristics: a clear language, a lively character, willingness to cultivate their bodies and their spirits 
According to the rules of the The Elementary Normal School of the Mie Prefecture (1893), every student should be careful to use a polite and dignified language, and to speak politely to his/her superiors. As in the case the Oita prefecture, there is a possibility that these rules concerning language refer to dialects, although this is merely an assumption as other sources related to this topic are not available.

However, it seems that, as far as the quality of language required from students is concerned, the emphasis is not on the dialectal uses. Listed below are words which indicate that:

Desirable qualities: accuracy and clarity, clear word endings, clarity, precision, articulate

Negative traits that need to be changed: speaking quietly, ambiguity, not finishing what one is saying, unclear endings

The instructions that can be found In the first category stipulate that the students should speak clearly and make themselves understood; moreover, they should always finish what they are saying and speak in a loud voice.

Just as in the case of phrases used at the end of sentences, there is of course a possiblity that these stipulations refer to dialects (or expressions that are perceived to be dialectal) which need to be changed. However, it also has to be emphasized that in every stipulation listed above, the focus is more on the manner of speaking than on dialectal expressions.

Apart from the school administration rules, more concrete rules can be found in an article, published in 1889 in Oita kyōritsu kyōiku about mid-term exams at elementary schools, more specifically in the section concerning assessment criteria. Cited below is item 3 from that section:

However, in oral exams there are students who are eloquent, convincing and show great skill in explaining the gist of things. On the other hand, there are students who stammer, who are inarticulate, speak in a very unclear manner, and are able to express their thoughts only if they are assisted by the teacher. Naturally, the differences between these two types of students should be reflected in their grades. That is because those students whose spoken language skills are poor will certainly do better in written tests than the students with good speaking abilities. (Hiroike, 1888)

This text refers to the "language imperfections", although the subjects of criticism here are "stammering" and "hesitancy", not dialects. Furthermore, according to the text, the students whose spoken language is "imperfect" and require the teacher's assistance, will certainly do well in written tests.

In conclusion to the present analysis, it could be said that in that period the concept of the "unclear language" referred to flaws related to speech, for example quiet voice, hesitancy, unclear word endings. Dialects, on the other hand, are not included in that category yet, at least not until later when Mukō treated them as a typical example 
of language opacity. Even in the stipulations and rules discussed above, no clear connection bewteen the concept of unclear language and dialects could be found.

\section{Conclusion}

In the present study, I have focussed on the belief, present from the Meiji Period to the Taishō Period in Japan, that a clear language yields a clear ideology. I have closely examined the following two points: the concepts that served as the basis for this belief, and the question whether there exist any substantial differences in the message conveyed by the concept of "opaque lanugage" during a period in which the general stance on dialects was different.

The answer to the first question I found in the philosopy of Pestalozzism, a widespread educational ideology during that period. When the method of object lessons was accepted in Japan it changed, which resulted in the inseparability of the precision of memory and knowledge acquisiton. That served as a basis for the belief described above.

In order to find an answer to the second question, I have examined a number of administrative regulations for elementary schools of that period. I have discovered that in the early Meiji Period, the idea of an "unclear language" included not so much dialects, but flaws like stammering, quiet voice or hesitancy. That is probably due to the fact that in that period, the definition of a dialect and the definition of a national language were still vague.

Pestalozzism as an educational doctrine started to wane after the first 20 years of the Meiji period. However, it still remained present as a belief which makes a connection between language and ideology. Furthermore, with the movement for the unification of the written and spoken styles of the Japanese language, and the RussoJapanese war, which boosted the national prestige, the national language became a popular subject of discourse. On the other hand, the dialect started to be viewed as a vulgar and primitive language. Some studies written during that period supported the idea that dialects should be destroyed, a stance adopted also by Mukai (1914).

Lastly, taking into consideration everything discussed above, I would like to examine the early Meiji period from the point of view of dialects. Yasuda (1999, p.48) disagrees with Shibata Takeshi (1958, p.111) who concurrs with the prediction by Miyake Yonekichi. Miyake claims that dialects will disappear naturally due to the development of public transportation, a point of view which Shibata evaluates as "a sound view, relevant to Contemporary Japan". Yasuda, on the other hand, believes that the creation of the transportational infrastructure or educational system serve to create an appearance of a unified state, with the "national power" in effect.

It can be said that Yasuda's claim is accurate. However, it should be noted that, compared to the studies written in later periods, the perception of the dialect in the 
early Meiji Period displays great diversity. Later on, the acceptance of occidental linguistics in Japan and the visible and invisible pressure from the state pervaded people's view on the language. The early Meiji Period was the time when the systematization of the "national langugage" was still at a developing stage, but the people attempted to produce definitions of their own language from a variety of different perspectives.

\section{References}

Aota, M. (1888). Hougen Kairyou ron. (Reformation of Dialect.) Fukushima: Shinshindo. from http://kindai.da.ndl.go.jp/info:ndljp/pid/868689/

Calkins, N. A., Kaneko N. (trans.), Takahashi K. (ed.). Shougaku Jugyou Hikkei. (The Companion to Elementary school classes.) Matsumoto: Keirindo.

Chibaken Jinjou Shihan Gakkou Fuzoku Shougakkou Kyouju Youshi. (Guidelines for Teaching at the Elementary School Affiliated to the Normal School of the Chiba Prefecture) (1893). Ooitaken Kyouritsu Kyouiku Zassi, 104, 18-23.

Hiroike, J. (1888). Shougakkou no Gakki Shiken. (The Semester Examination of Elementary School.) Ooitaken Kyouritsu Kyouiku Zassi, 39, 7-10.

Hojo, S. (1890). Gakuji Shisatsu. (School observation.) Ooitaken Kyouritsu Kyouiku Zassi, 67 , 28-35.

Ito, T. (1995). Pestalozzi's Quest for the "Right" Question-Answer-From : His Proposition and Its Limits. Annual of Educational Study, 12, 81-93. Nara woman's university.

Kuroda, S. (1889). Tankyuu Kyouju Seiseki Houkoku. (The Report of the One-class School Teaching and Their Learning Results.) Ooitaken Kyouritsu Kyouiku Zassi, 52, 20-31 \& 53, 31-41.

Lee, Y. (1996). “Kokugo” to iu Shiso. (The thought of Japanese National Language named "Kokugo") Tokyo: Iwanami shoten.

Matsubara, K. (1888). Sakubun Kyouju ni Tsuite no Kouan. (Some Ideas for Composition Lesson.) Ooitaken Kyouritsu Kyouiku Zassi, 40, 19-23.

Mieken Jinjou Shihan Gakkou Fuzoku Shougakkou Kyouiku Youshi. (The Rules of Behaviour at the Elementary School Affiliated to The Normal School of the Mie Prefecture) (1893). Ooitaken Kyouritsu Kyouiku Zassi, 104, 18-23.

Mino?, T. (1888). Gengo Renshuu no Hitsuyou. (The Importance of Language Practice.) Ooitaken Kyouritsu Kyouiku Zassi, 39, 5-7.

Miyake, Y. (1929). Hougen Torishirabe Nakama no Shuisho. (Statement of Intent-The Research circle of dialects.) In Bungaku Hakase Miyake Yonekichi Chojutsusyuu Joukan, 849. Tokyo: Meguro Shoten.

Morokuzu, N. (1875). Shōgaku kyōshi hikkei. (The Companion to Elementary School Teacher.) Tokyo: Seizando.

Mukai, G. (1914). Boukokuteki Kyouiku wo Haishite Koukokuteki Kyouiku wo Susumu.(Encouraging Use of Prosperous Education instead of Treasonable one.) Сһииои Kouron, 312, 52-68.

Osa, S. (1998). Kindai Nihon to Kokugo Nashonarizumu. (The Modern Japan and Nationalism in National Language.) Tokyo: Yoshikawa Koubunkan.

Shibata, T. (1958). Nihon no Hougen. (The dialect of Japan.) Tokyo, Iwanami Shinsho. 
Shizuokaken Jinjou Shihan Gakkou Fuzoku Shougakkou Kyouju Ippan. (The Teaching

Methods at the Elementary School Affiliated to The Normal School of the Shizuoka

Prefecture.) (1891). Ooitaken Kyouritsu Kyouiku Zassi, 81, 37-39.

Wakabayashi T. \& Shirai, K. (1883). Kaisei Kyoju jutsu. (A Revision of Teaching Techniques)

Yano, M. (1907). Ichi-kou yori. (From Dai-ichi high school.) Shuиуuи, 15, 39-42.

Yasuda, T. (1999). Kokugo to Hougen no Aida - Gengo Kouchiku no Seijigaku. (Between National Language and Dialect - Politics in the construction of Language.) Tokyo: Jinbun shoin. 